International Journal of Engineering \& Technology, $7(2)(2018) 520-525$
International Journal of Engineering \& Technology
SPC
Website: www.sciencepubco.com/index.php/IJET
doi: $10.14419 /$ ijet.v7i2.9308
Research paper

\title{
Influence of dike slope on the development of infiltration water and erosion processes during overtopping tests
}

\author{
Marwan Adil Hassan ${ }^{1}$ *, Mohd Ashraf Mohamad Ismail ${ }^{2}$ \\ ${ }^{1}$ Ph.D. Student, School of Civil engineering, Universiti Sains Malaysia, Engineering Campus, \\ 14300 Nibong Tebal, Pulau Pinang, Malaysia \\ ${ }^{2}$ Senior Lecturer, School of Civil engineering, Universiti Sains Malaysia, Engineering Campus, \\ 14300 Nibong Tebal, Pulau Pinang, Malaysia \\ *Corresponding author E-mail: eng.marwanadil@gmail.com
}

\begin{abstract}
The usage of dikes embankments has a great influence on the development of hydraulic engineering. It increases the suitability of water resources for humanity needs. Different Geotechnical and hydraulics powers affect on the stability of dike construction through transition of water flow in the upstream slope. The development of erosion process inside dike construction occurred as a result of an overtopping water flow cross above the dike crest. The dike erosion initiates breach channel inside dike and later widened into upstream and downstream slopes. In this study, a 2D and 3D vertical and horizontal erosions test is constructed in Hydraulic Geotechnical laboratories at the Universiti Sains Malaysia to observe the evolution of the breach channel during spatial overtopping failure. Two constant dike slopes of $(1 \mathrm{~V}: 3 \mathrm{H})$ and $(1 \mathrm{~V}: 2.5 \mathrm{H})$ for both upstream and downstream slopes are used as a parametric test during overtopping tests. The vertical and horizontal distributions of water levels are also highlighted prior to overtopping failure. The results indicate that the vertical and horizontal erosion widen the dike breach for slope of $1 \mathrm{~V}: 2.5 \mathrm{H}$ faster than those for $1 \mathrm{~V}: 3 \mathrm{H}$ while the spread of water infiltration in horizontal and vertical levels are higher for latter slope than for previous one.
\end{abstract}

Keywords: Dike; Horizontal Erosion Process; Overtopping Failure; Pilot Channel; Vertical Erosion Process.

\section{Introduction}

Dikes are earthfill materials used to prevent the dangers of water flooding from destroying lives and properties, providing power generation and maintain sediment retention [1], [2]. The overtopping failure is one of most familiar failures effects on dikes as well as dam constructions [3], [4], [5]. It occurred due to transit water flow above dike crest; consequently, the sediment material is transported due to erosion process along the foot of the dike for the homogeneous and composite dike. The shape of the breach channel during the erosion process is triangular, rectangular and trapezoidal. Most of studies assume the final shape of breach as trapezoidal [6], [7]. The dike slope instability is studied through a series of both 2D planar and 3D spatial tests for cohesive and non -cohesive soil in laboratory and field studies. They are focusing on dike breach simulation and parameters effecting on development of erosion process inside dike breach channel [8], [9], [10]. The mechanism of breach channel development during overtopping tests has been addressed by several researchers [11], [12]. Visser [13] discovered five stages described the breach process in sand dikes. These stages are very similar to stage process described by Zhu et al. [14] for cohesive dike embankments. Pickert et al. [15] and Pickert et al. [16] observed the mechanism of breach channel during the 3-D overtopping test under different soil grain sizes. They noticed that fine particles have different erosion patterns during the overtopping failure and the side-slope failure will likely occur due to the faster saturation process. Chinnarasri et al. [17] studied the behavior of homogeneous embankment soil during the progression of erosion process inside the rectangular pilot channel.
Side slope instability and tractive shear forces were reduced the stability of the dike; consequently, the collapse of dike body occurred. Schmocker and Hager [18] constructed trapezoidal embankment dikes with different grain sizes and embankment geometry- at the Laboratory of Hydraulics of the Swiss Federal Institute of Technology in Zurich- to observe the lateral erosion process under different scale factors.

Dikes with large dimensions tend to erode faster due to high turbulence intensities. Bigger grain size increases the widening of the breach channel because of the contribution of sliding failure in collapses downstream slope. A series of embankment tests were constructed in in the Dawa Reservoir, Chuzhou, Anhui province, China to notice the development of erosion process inside the dikes constructed with cohesive materials [19]. They divided the behavior of dike failures into three; headcut failure in dike materials, 'helix flow' in side of breach channel and side-slope failure in the centerline of breach channel. The author has investigated the effect of inflow discharges on the development of negative pore water pressure and water content inside coarse sand embankment. A pilot channel was cut along the PVC flume channel to initiate the spatial overtopping test. He observed that the higher inflow discharges increased the volumetric water content faster than that for lower inflow discharges and thus further decreased the matric suction for the higher inflow [20]. The main goals of this study is to describe the mechanism behavior of erosion processes as well as the distribution of vertical and horizontal water levels inside pilot channel of sand dike under two different dike slopes of $1 \mathrm{~V}: 3 \mathrm{H}$ and $1 \mathrm{~V}: 2.5 \mathrm{H}$. The dike slopes of $1 \mathrm{~V}: 3 \mathrm{H}$ and $1 \mathrm{~V}: 2.5 \mathrm{H}$ are termed as "E1" and "E2", respectively. 


\section{Experimental test setup}

Up to two spatial overtopping tests are conducted at in Hydraulic Geotechnical laboratories at the Universiti Sains of Malaysia to determine the evolution of both vertical and horizontal erosion processes during overtopping failure as well as the distribution of water levels inside the dike. The dimensions of the trapezoidal sand dike are 190 and $160 \mathrm{~cm}$ length for E1 and E2, respectively, $50 \mathrm{~cm}$ width, and $30 \mathrm{~cm}$ crest height. Dikes are comprised of poorly graded coarse sand. A pilot channel of $10 \mathrm{~cm}$ length, $4 \mathrm{~cm}$ width and $3 \mathrm{~cm}$ depth was cut at the dike crest along the side wall of PVC channel to initiate breach channel as shown in fig. 1 and fig. 2 for E1 and E2, respectively. The homogeneous dikes are constructed in the PVC small flume channel with dimensions of 450,50 , and $60 \mathrm{~cm}$ in length, width, and height, respectively. The dike soil is classified as poorly graded coarse sand as shown in Table 1.

\begin{tabular}{|c|c|c|c|c|}
\hline \multicolumn{2}{|c|}{ Dike components $(\%)$} & Parameters $(\mathrm{mm})$ & $\left(\mathrm{C}_{\mathrm{u}}\right)$ & $\left(\mathrm{C}_{\mathrm{c}}\right)$ \\
\hline Sand & 80.59 & $\mathrm{D}_{60}=1$ & & \\
\hline Gravel & 19.1 & $\mathrm{D}_{30}=0.58$ & & \\
\hline Silt \&Clay & 0.31 & $\mathrm{D}_{10}=0.33$ & 3.03 & 1.019 \\
\hline
\end{tabular}

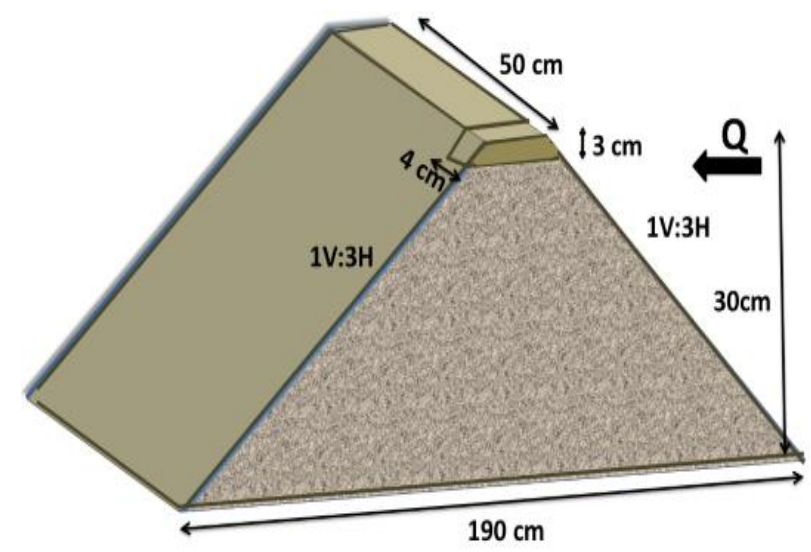

Fig. 1: Geometry of Dike Construction with Pilot Channel Location (Shaded Area) For E1.

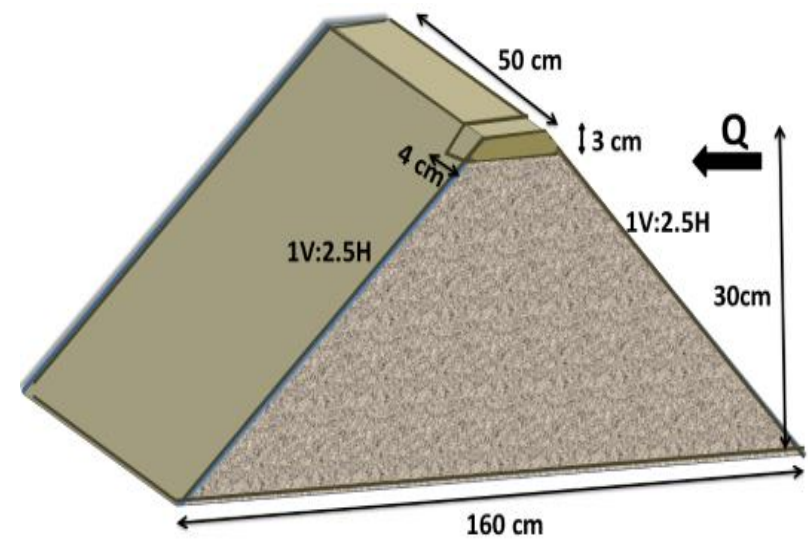

Fig. 2: Geometry of Dike Construction with Pilot Channel Location (Shaded Area) for E2.

The upstream and downstream slopes dimensions are identical for both slopes under constant inflow discharges of $30 \mathrm{~L} / \mathrm{min}$. The flume channel is supplied with water from Flow meter connected with the maximum pump discharge of $\mathrm{Q}=70 \mathrm{l} / \mathrm{min}$. The sediment box is placed at the end of the flume channel to collect the eroded materials during overtopping test. The developments of the lateral and vertical breach channel as well as the distribution of water levels are recorded and analyzed through two digital cameras installed in front of the PVC flume channel and downstream slope, respectively as shown in Fig. 3.
(A)

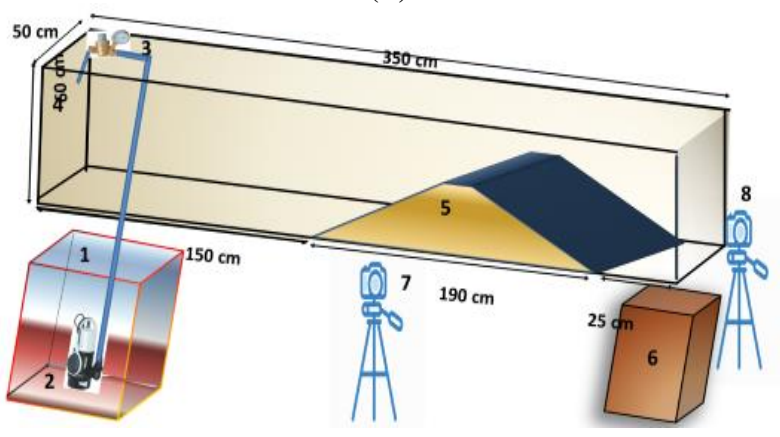

(B)

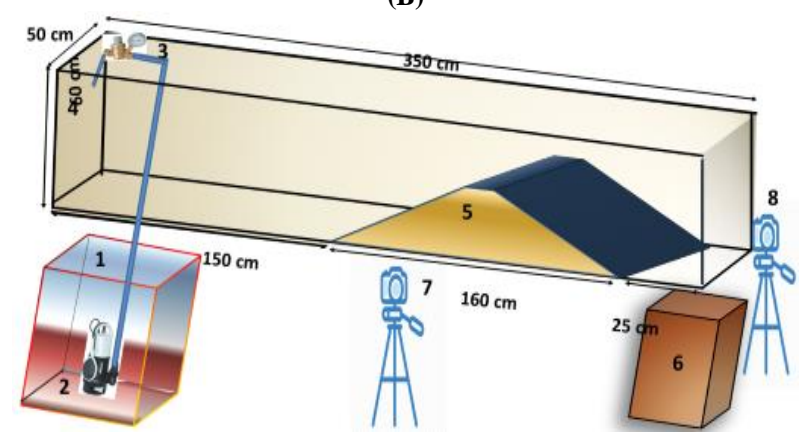

Fig. 3: Component Parts of Flume Channel: 1) Water Tank, 2) Discharge Pump, 3) Flowmeter, 4) Flume Channel, 5) Dike Construction, 6) Sediment Tank, 7, 8) Camera for: A) E1, B) E2.

\subsection{Tests procedures}

The sand embankment is prepared first by applying temperature heat of $105^{\circ} \mathrm{C}$ on the sand inside oven dry in order to exclude water content from soil particles (dry condition). The arrangement of soil inside flume is embedded gradually during dike construction. The soil is divided into three levels of $10 \mathrm{~cm}$ while each layer is compacted for accomplishing soil density of $1.8 \mathrm{~g} / \mathrm{cm}^{3}$ for each one. The pilot channel is then cut inside dike crest and along the side of the PVC channel to initiate overtopping failure. A Constant inflow discharge of $30 \mathrm{~L} / \mathrm{min}$ is used for both slopes experiments while all other parameters are kept constant. The inflow discharge was added fast to attain steady state discharge before overtopping. The experiments started from the beginning of transient water flow above upstream slope, then crossed into the downstream slope through pilot channel. The determinations of dike erosion processes in vertical and horizontal directions as well as the distribution of water levels are analyzed from photos of two digital cameras. The tests ended when most sediment materials eroded or when erosion process stabilizes.

\section{Results and discussion}

Fig. 4 and fig. 5 show the infiltration of water levels inside the dike for E1 and E2, respectively under the constant inflow of 30L/min, while infiltration water transmitted from the toe of the upstream slope until dike crest. The infiltration water is captured through using digital camera installed in front of the PVC flume channel. Although the development of breach channel is dependent on the changeable water level in the river, the constant inflow could be applied in practice use for simplicity. The constant inflow discharges continued until the end of tests. The Y-axis represents the dike height plotted against the $\mathrm{X}$-axis of horizontal dike length during certain times of transient water levels in seconds. The infiltration of water helps to increase volumetric water content and decrease soil suction inside soil particles at each time during overtopping tests for E1 and E2. Consequently, the percentage of water content increases and a saturation process occurred faster for both tests. The vertical soil water pressure migrates the infiltrated water from particles of the lower tension zone into the soils of the high 
tension zone in which speed and rise of water penetration are dependent basically on soil permeability. As the infiltration process increases, the permeability of soil to water infiltration increases and thus a large amount of soil particles are filled up gradually with phreatic water level for the whole dike construction. For E1, the infiltration process is faster filled up the soil particles for E1 than that for E2 in the toe and the middle of the upstream slope due to the easy water infiltration into dry soil through the inclination flat slope. The heights of water level are $3 \mathrm{~cm}$ and $2 \mathrm{~cm}$ at $\mathrm{t}$ $=10$ second for E1 and E2, respectively. The phreatic water level for $\mathrm{E} 1$ is reached the middle of the upstream dike slope at $\mathrm{t}=200$ second while for E2 it is contacted at $\mathrm{t}=220$ seconds. The shear strength of soil starts to decrease gradually and thus the instability of dike slope and breach channel evolution occurred inside pilot channel and expanded in downstream and upstream slopes.

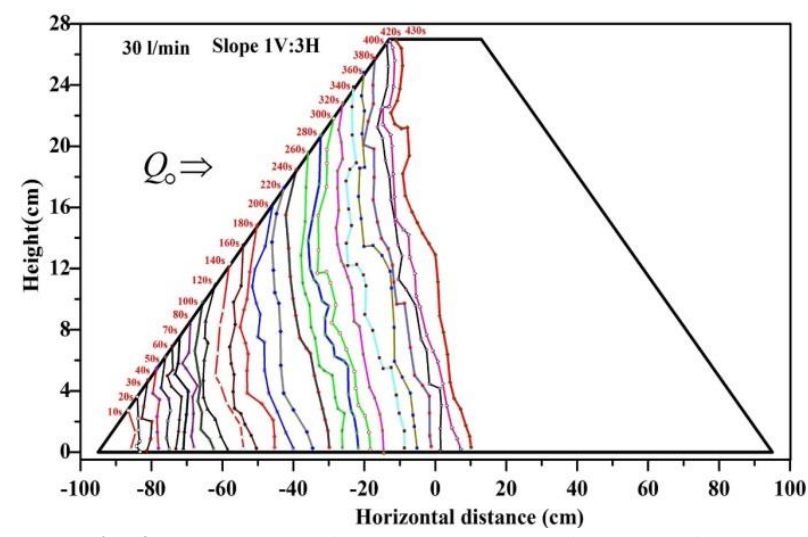

Fig. 4: Water Flow Infiltration inside Dike for Slope of E1.

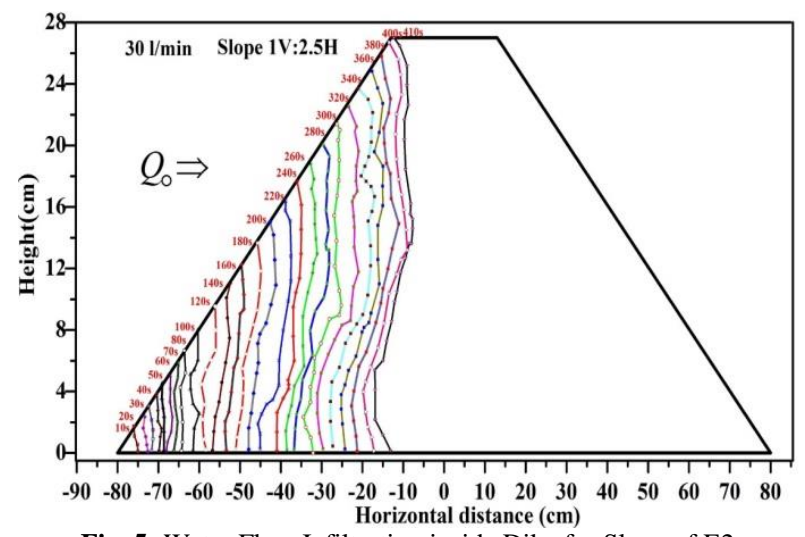

Fig. 5: Water Flow Infiltration inside Dike for Slope of E2.

Fig.6 and fig. 7 show the distribution of vertical and horizontal water levels inside dike soil for E1 and E2, respectively. The vertical water level is measured from the toe of upstream slope, at $\mathrm{t}=$ zero second, until a maximum value in dike crest. The horizontal water level is calculated from the beginning of entering water in upstream slope toe and through the horizontal distance of dike length till the maximum value in the toe of downstream slope. The horizontal water level is penetrated soil particles faster than vertical levels for both slopes tests because the gravity reduces the raising of the vertical water level while soil voids in the horizontal level are located in the base of dike construction and thus eliminate the effect of gravity. Consequently, more voids are saturated in the horizontal direction of dike length for both E1 and E2. The soil particles are distributed first in horizontal direction and then transferred up into particles in the vertical direction. For E1, the vertical and horizontal water levels in the beginning of water infiltration at $\mathrm{t}=1$ minute are 6.9 and $23.5 \mathrm{~cm}$, respectively, while in the middle of dike height, they are $16 \mathrm{~cm}$ and $55 \mathrm{~cm}$ at $\mathrm{t}=3.33$ minutes, respectively. In the dike crest at $t=7.16$ minutes, the vertical water level increased into $26.9 \mathrm{~cm}$ and the horizontal water level climbed into $105 \mathrm{~cm}$ in the transition area between upstream and downstream slopes. The vertical water levels for E1 and E2 are faster in the toe and the middle of the upstream slope due to the faster water saturation process in flat slope of E1 in which the vertical water levels for E1 and E2 are 2.7 and $1.7 \mathrm{~cm}$, respectively at $\mathrm{t}=0.166$ minutes. The differences between vertical levels for E1 and E2 are decreased gradually after $t=2$ minutes in which both vertical levels are nearly identical at $\mathrm{t}=6$ minutes as shown in fig. 8 while The vertical water levels are 24.82 and $24.8 \mathrm{~cm}$, respectively for E1 and E2 for the latter time. The permeability of saturated voids to infiltration water is reduced due to the constant crest length and thus smallest dike volume near the dike crest for E1 and E2. At the dike crest, the vertical water level is contacted faster for E2 than that for E1 at $t=6.83$ and 7.16 minutes, respectively. This is due to flat slope of E1 that raising the vertical level faster in the toe of upstream slope and the middle of dike slope. The large horizontal distance of E1 delayed the rising of vertical water level, compared with E2, near dike crest due to the remaining non saturated voids in the transition area between upstream and downstream slopes and downstream slope, and thus decreased water velocity and turbulence. Contrarily, the horizontal water level is clearly faster in E1 than in E2 at $t=1$ minute as shown in fig. 9 with horizontal water levels of 23.5 and $13.5 \mathrm{~cm}$, respectively. Particles voids near the upstream slope are stiffer in E2 than those in E1 due to the steep slope of the previous slope and thus deaccelerate the horizontal water level. The steep slope of E2 reduces the easiest infiltration process because of the particle's position against gravity.

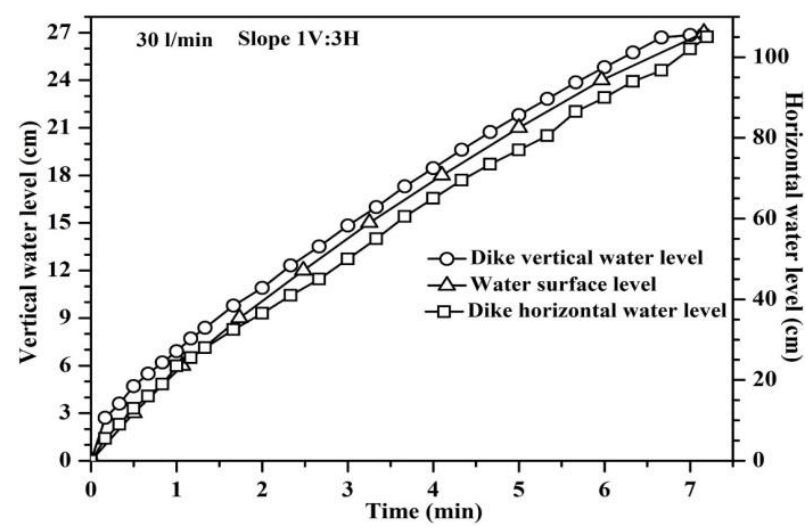

Fig. 6: Distribution of Water Surface Levels for Slope of E1.

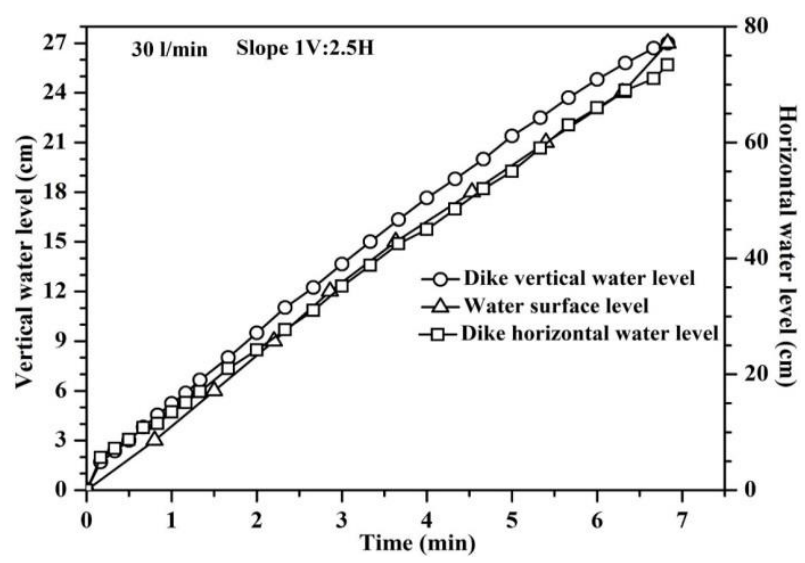

Fig. 7: Distribution of Water Surface Levels for Slope of E2. 


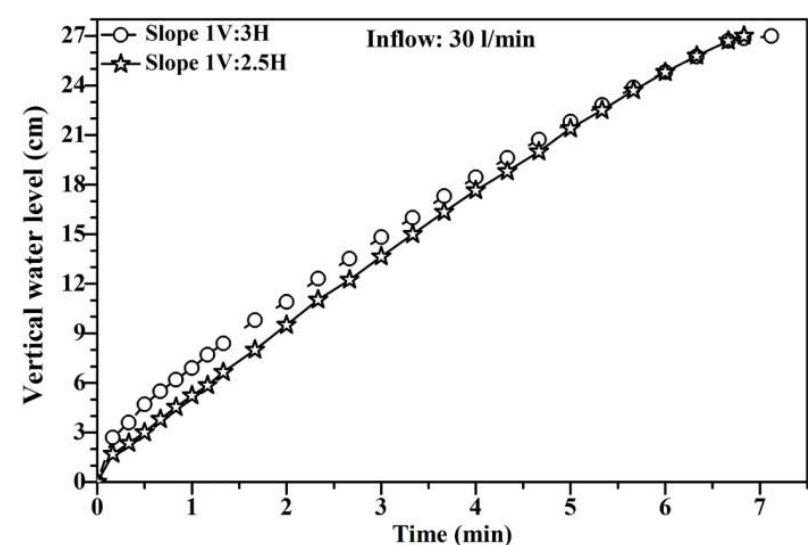

Fig. 8: Comparison Results between Vertical Water Levels for E1 and E2.

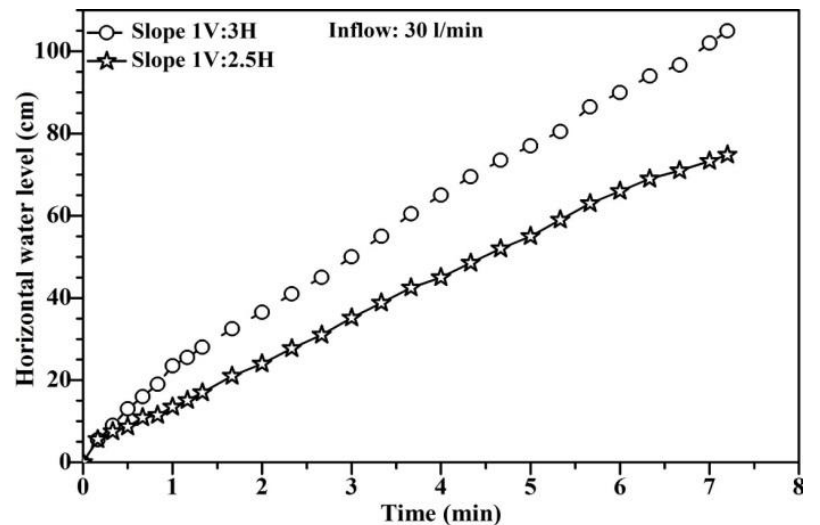

Fig. 9: Comparison Results between Horizontal Water Levels for E1 and E2.

Fig. 10 and fig. 11 show dike breach profile of vertical erosion process for slopes of E1 and E2, respectively recorded with side camera. The vertical erosion for dike profile is plotted against the horizontal distance of the dike length of $175 \mathrm{~cm}$. The breach channel started during the water flow cross inside the pilot channel at $\mathrm{t}=$ zero second downward into downstream and upstream slopes. The processes of eroded materials for E1 and E2 are moved slowly at $\mathrm{t}=10$ seconds with small amount of sediments transported along the downstream dike crest as debris flow. At $t=60$ seconds, the erosion rate reached the middle of the downstream slope due to accelerate the breach flow over the lower part of downstream slope in which huge parts of the downstream slope collapsed. The breach channel is then enlarged in downstream and upstream slopes in latter seconds. Almost half of dike body is eroded due to horizontal and vertical erosion process in 120 and 100 seconds for E1 and E2, respectively, with huge increasing of the tailwater wedge of sediments eroded along the flume channel in which the sediment materials transported into sediment box. The enlargement of breach channel, extended in the upstream slope, is continued until the breach profile of dike became constant with negligible erosion process at $\mathrm{t}=190$ and 180 seconds for E1 and E2, respectively. At these time periods, the height of dike crest is almost disappeared due to progression of water velocity. The final dike breach profile is similar for all dike slopes at the end of erosion.

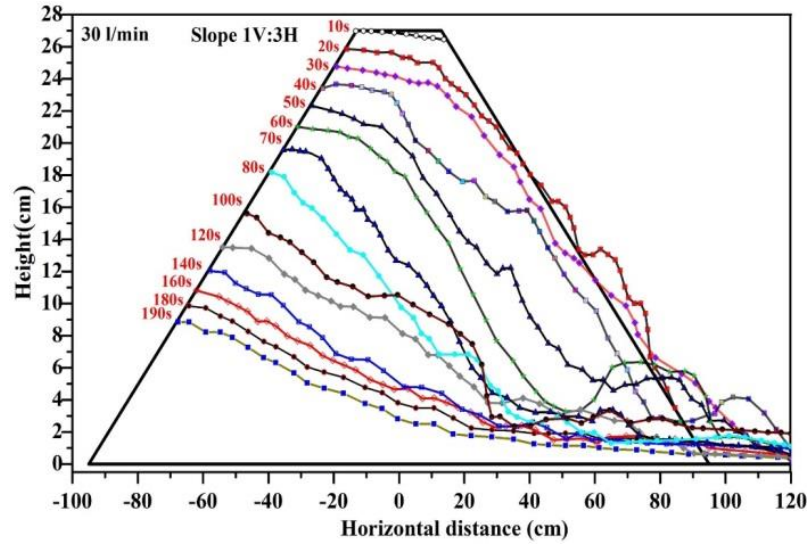

Fig. 10: Dike Breach Profile in Vertical Erosion Process of E1.



Fig. 11: Dike Breach Profile in Vertical Erosion Process of E2.

Fig. 12 shows the comparison reduction of dike height between dike slopes of E1 and E2 due to vertical erosion process inside the pilot channel. The slight reductions of dike heights in dike crest, at $\mathrm{t}=10$ second, are 26.97 and $26.87 \mathrm{~cm}$ for E1 and E2, respectively, are occurring due to high material quantity and lower water velocity. The downstream side slope failure is occurring distinctly at $\mathrm{t}=40$ second, due to the development of water content inside particles, while the dike crest heights decreased in 23.65 and 23.15 $\mathrm{cm}$ for E1 and E2, respectively. The process of longitudinal breach channel for E2 is faster than for E1 in the middle and toe sections of the downstream slope due to the effect of a steep slope in which the dike heights are 13.5 and $12.5 \mathrm{~cm}$ for E1 and E2, respectively at $\mathrm{t}=120$ second due to increase water velocity above E2 higher than that for E1 and thus the energy slope is higher. The flow condition in the dike crest is transitional and changed into supercritical flow in the downstream dike slope and thus the lateral erosion accelerate in the downstream direction faster for E2. During this flow condition, the soil shear strength is decreased and the vertical downstream slope is saturated enough to overcome the soil resistance stress while material gradually eroded and transported along the toe of the downstream slope into sediment box. The rate of water velocity is decreased gradually in the end of erosion at $\mathrm{t}=190$ and 180 seconds due to the continued reduction of dike height near the toe of the downstream slope in which the material eroded mechanism are stabilized with dike heights of 9.4 and 8.8 $\mathrm{cm}$ for E1 and E2, respectively. 


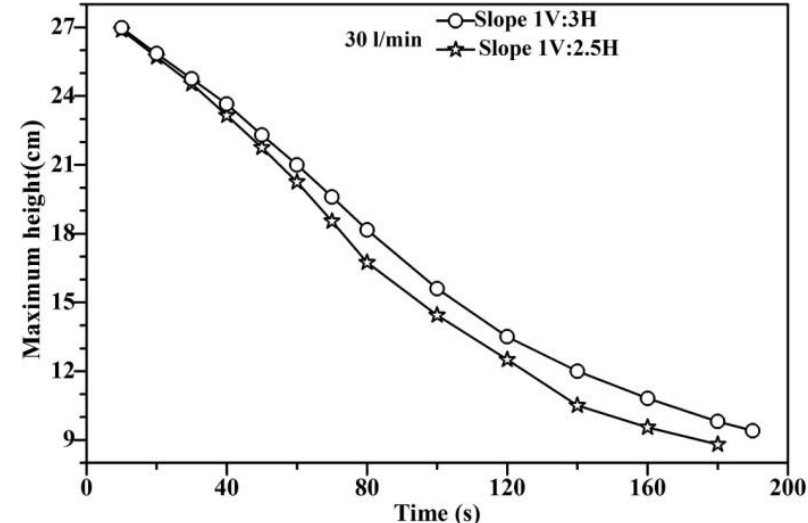

Fig. 12: Comparison Results of Lowering Dike Heights inside the Pilot Channel.

For better understanding the behavior of dike soil erosion, 3D fully spatial tests are highlighted and recorded with a camera in front of downstream slope. Fig. 13 and fig. 14 represent the development of lateral erosion process during overtopping tests for E1 and E2, respectively. The reductions of dike width are plotted against the horizontal width distance of $50 \mathrm{~cm}$ for E1 and E2. The process of lateral erosion started with water crossing the pilot channel at $\mathrm{t}=$ zero second. The reductions of widths are less in the beginning of overtopping failure for both E1 and E2, while the main erosion process for this period is vertical erosion process due to the quickly saturation of dike crest layer below pilot channel. The noticeable reduction of dike width occurred at 30 and $10 \mathrm{sec}-$ onds for E1 and E2, respectively. At these moments, the toe of downstream slope is stable due to lower water velocity while the horizontal erosion occurred in dike crest. At $\mathrm{t}=50$ and 20 seconds, the dike width expanded laterally in the middle and toe of the downstream slope for E1 and E2, respectively. This is because of increasing shear stress and thus increasing the undermining of breach channel side slopes. The vertical dike slope is fully saturated in later seconds; consequently, huge amount of soil materials is collapsed and fall down into the bed flume channel. At the end of later erosion process at 190 and 180 seconds for E1 and E2, respectively, the erosion rate inside dike was stabilized and the hourglass breach shape is formed due to negative pore water pressure of soil.

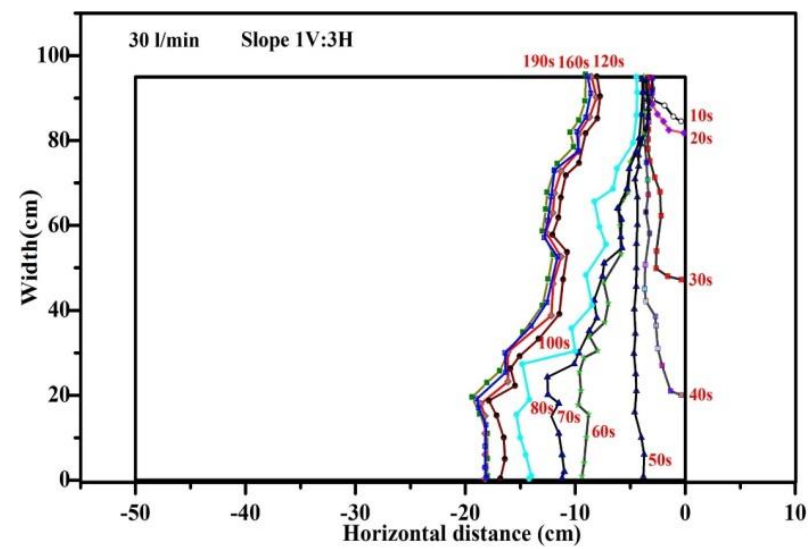

Fig. 13: Reduction of Dike Width Due to Lateral Erosion Process for E1.

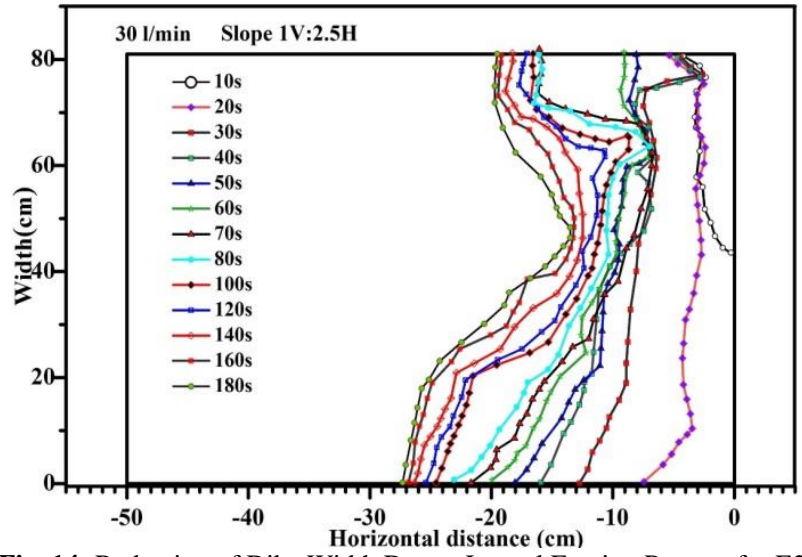

Fig. 14: Reduction of Dike Width Due to Lateral Erosion Process for E2.

Fig. 15 shows the comparison reduction of dike width for E1 compared with that for E2. The effect of dike slope in width reduction, during the early erosion process, is less visible in top and invisible in the middle and toe sections due to less turbulence and materials resistance in the dike crest at $\mathrm{t}=10$ seconds for $\mathrm{E} 1$ and E2 in which the dike widths are 3 and $4.19 \mathrm{~cm}$, respectively. The toe and top sections are progressively saturated due to increase velocity and tractive shear stresses in downstream slope with noticeable differences of dike widths of 3.04 and $7.42 \mathrm{~cm}$ at $\mathrm{t}=20$ second for E1 and E2, respectively. Consequently, most of materials collapsed into the breach channel center due to the steep slope of E2 while most of the transition area between upstream and downstream slopes and upstream slope are eroded at $\mathrm{t}=70$ second. The reduction dike widths are 12.54 and $21.66 \mathrm{~cm}$ for E1 and E2, respectively. The steep slope of E2 increases the velocity of breach flow over the downstream slope and thus accelerate the breach erosion compared with E1. Over the time, the erosion process is decreased during continuous reduction of dike height due to decrease tractive shear stresses and energy head and thus, erosion slows down at $\mathrm{t}=190$ and 180 seconds with dike widths of 19.38 and $27.29 \mathrm{~cm}$ for E1 and E2, respectively From all above figures, the lateral erosion process is faster in E2 than that in E1 due to higher saturation process during overtopping tests, while for E1 the development of breach channel is slow due to flat slope, and thus collapses of materials are delayed.

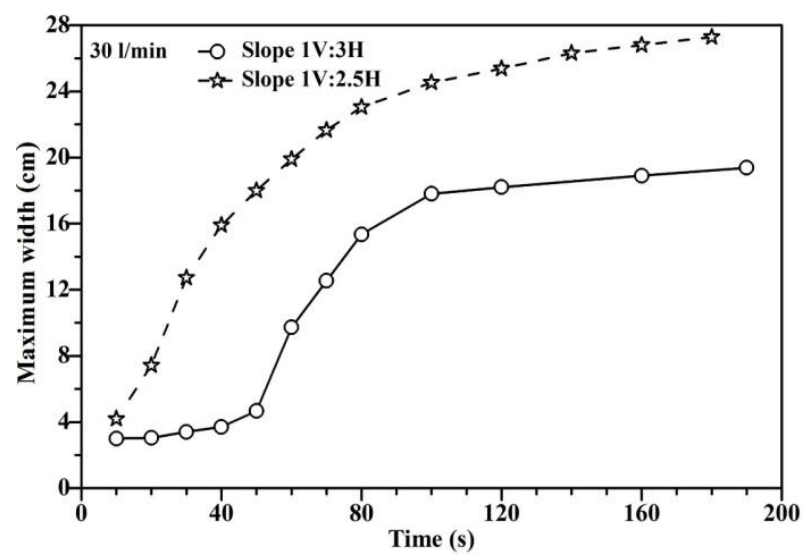

Fig. 15: Comparison Results of Reduction Dike Widths inside Pilot Channel.

\section{Conclusion}

This paper has discussed the infiltration of inflow water inside the dike construction as well as vertical and lateral erosion processes during spatial overtopping tests. The homogenous sand dikes are constructed inside flume channel under a constant inflow discharge of $30 \mathrm{~L} / \mathrm{min}$ with the assistance of two digital cameras. The results indicated that horizontal water level is faster than the vertical water level for both E1 and E2 due to resistance of gravity against water infiltration inside the particles. The vertical water 
level is relatively close in the toe section for both dike tests and then possessively increased in the middle of the upstream slope for E1 higher than E2 while it is gradually deaccelerated for previous slope near dike crest due to large longitudinal dike length for E1. Both of lateral and vertical erosion processes in breach channel are faster in E2 than in E1 due to steepness slope. The reduction for dike height and width are non-noticeable near the dike crest for both E1 and E2 due to high soil density. During the evaluation of breach channel, the water velocity accelerated in the lower portion of downstream slope and thus collapsed of materials in downstream and upstream slopes occurred along the bottom of flume channel. The saturation process has taken longer period in E1 due to increase dike volume and thus delayed the process of dike erosion at the end of overtopping tests.

\section{Acknowledgment}

The authors acknowledge the assistance and cooperation provided by the department of hydraulic and civil engineering in the Universiti Sains of Malaysia.

\section{References}

[1] P. Bahattari, H. Nakagawa, K. Kawaike, H. Zhang, Experimental study on effect of sediment size on river dyke breach characteristics due to overtopping, Japan Society for Natural Disaster Science 33 (2014) 65-74. URL:http://hd1handle.net/2433/196121.

[2] M. Hassan, M.A. Ismail, Literature review for the development of dike's breach channel mechanism caused by erosion processes during overtopping failure, Engineering Heritage Journal / Galeri Warisan Kejuruteraan 1(2017) 23-30.doi: https://doi.org/10.26480/gwk.02.2017.23.30.

[3] M. Foster, R. Fell, M. Spannagle,. The statistics of embankment dam failures and accidents, Canadian Geotechnical Journal 37(2000) 1000-1024. https://doi.org/10.1139/t00-030.

[4] V.P. Singh, C.A. Quiroga, Dimensionless analytical solutions for dam-breach erosion, Journal of Hydraulic Research 26 (1988) 179 197. https://doi.org/10.1080/00221688809499224.

[5] M. Rico, G. Benito, A. Diez-Herrero, Floods from tailings dam failures, Journal of Hazardous Materials, 154 (2008) 79-87. https://doi.org/10.1016/j.jhazmat.2007.09.110.

[6] T.C. Macdonald, J. Langridge-Monopolis, Breaching characteristics of dam failures, Journal of Hydraulic Engineering 110(1984) 567586. DOI: 10.1061/ (ASCE) 0733-9429(1984)110:5(567).

[7] V. Manville, Techniques for evaluating the size of potential dambreak floods from natural dams, Institute of Geological \& Nuclear Sciences Science Report, New Zealand, (2001).

[8] R.A. Wurbs, Dam-breach flood wave models, Journal of Hydraulic Engineering, 113(1987) 29-46. Doi: 10.1061/(ASCE)0733 - 9429 (1987) 113:1(29).

[9] P. Shuibo, Q. Mingsen, W. Liangxian, X et al, Part I: Investigation report on dam safety research in China, Publications of the Water and Environment Administration - series A 167, http://hdl.handle.net/10138/29795, 1993.

[10] D. Stretch, and M. Parkinson, The breaching of sand barriers at perched, temporary, open/closed estuaries - A model study, Coastal $\begin{array}{llll}\text { Engineering Journal, } 48 \text { (2006) } & \end{array}$ https://doi.org/10.1142/S0578563406001295.

[11] P.J. Visser, Y. Zhu, J.K. Vrijling, Breaching of dikes, Proceeding of 30th International conference on Coastal Engineering, California, 2006. https://doi.org/10.1142/97898127095540244.

[12] M. Wong, G. Parker, Reanalysis and correction of bed-load relation of Meyer- Peter and Müller using their own database, Journal of Hydraulic Engineering, 132 (2010) 1159-1168. DOI: 10.1061/ (ASCE) 0733-9429 (2006) 132:11(1159).

[13] P.J Visser, Breach erosion in sand-dikes, proceeding of 26th International Conference on Coastal Engineering, Copenhagen, 1999. https://doi.org/10.1061/9780784404119.267.

[14] Y. Zhu, P.J. Visser, J.K. Vrijling, A model for headcut erosion during embankment breaching, Proceeding of 4th International Association for Hydro-Environment Engineering Coastal and Estuarine Morphodynamics, Illinois, 2005a https://doi.org/10.1201/9781439833896.

[15] G. Pickert, V. Weitbrecht, A. Bieberstein, Breaching of overtopped river embankments controlled by apparent cohesion, Journal of Hy- $\begin{array}{llr}\text { draulic } & \text { Research, } & 49(2001) \\ \text { https://doi.org/10.1080/00221686.2011.552468. }\end{array}$

[16] G. Pickert, G.H. Jirka, A. Bieberstein, J. Brauns, Soil/water interaction during the breaching process of overtopped embankments, Proceeding of 2nd International Fluvial Hydraulic, Naples, 2004. https://doi.org/10.1201/b16998-115.

[17] C. Chinnarasri, S. Jirakitlerd, S. Wongwises, Embankment dam breach and its outflow characteristics, Civil Engineering and Environmental Systems, 21(2004) 247-264. https://doi.org/10.1080/10286600412331328622.

[18] L. Schmocker, W.H. Hager, Modelling dike breaching due to overtopping, Journal of Hydraulic Research, 47(2009) 585-597. Doi: https://doi.org/10.3826/jhr.2009.3586.

[19] L.M. Zhang, Y. Xu, J.S Jia, Analysis of earth dam failures: A database approach, Georisk: Assessment and Management of Risk for Engineering Systems and Geohazards, 3(2009) 184-189. https://doi.org/10.1080/17499510902831759.

[20] M. Hassan, and M.A. Ismail, Effect of inflow discharges on the development of matric suction and volumetric water content for dike during overtopping tests, Proceeding of American Institute of Physics conferences, Penang, $2017 . \quad$ DOI: https://doi.org/10.1063/1.5005675. 